\title{
COMPARATIVE HEPATOPROTECTIVE EFFICACY OF SILYMARIN- PHYLLANTHUS-CHOLINE COMBINATION VERSUS SILYMARIN ALONE IN LIVER DISEASES WITH DIFFERENT DESTRUCTION AND INFLAMMATION STAGES
}

\author{
OVIDIU FRĂȚILA ${ }^{1 *}$, ADINA IOANA MIHELE ${ }^{2}$, EVA FLORINA HODISAN-PAP $^{2}$, SERGIU \\ CRISTIAN HOCOPAN ${ }^{2}$, ROXANA BRATA ${ }^{1}$, TIBERIA ILIAȘ ${ }^{1}$ \\ ${ }^{1}$ Department of Medical Disciplines, Faculty of Medicine and Pharmacy, University of Oradea, Romania \\ ${ }^{2}$ University of Oradea, Romania
}

*corresponding author: ovidiufr@yahoo.co.uk

\begin{abstract}
Chronic liver diseases of the adult represent one of the most important part of the daily medical practice due to a high prevalence and incidence. A number of synthetic as well as plant-based drugs, are used for various liver diseases. Synthetic drugs, although highly effective, come with adverse effects whereas plant-based drugs have a clearly better safety profile. The most studied and used plant-based remedy for hepatic disorders is Silybum marianum seeds extract standardized in silymarin. However, plant-based products are often described as having a lower efficacy which entails the need of higher and multiple doses in a long-time treatment. That is why the idea of a combination between several hepatoprotectives for a synergistic effect rises as logical and necessary. The present research aimed to evaluate the hepatoprotective effect of the combination silymarin + Phyllanthus niruri extract + choline versus the effect of silymarin alone in higher dose in patients with various hepatic disorders. The patients included in the study were adults diagnosed with different hepatic disorders (viral hepatitis B or C, compensated cirrhosis, steatohepatitis) and then randomized between the two hepatoprotective treatment groups. Hepatoprotective treatments were administered daily for 180 days and the patients were investigated initially and then 3 and 6 months later for specific biomarkers and Fatty liver index (FLI) as a parameter for the degree of hepatic steatosis. The results demonstrated the superior efficacy of silymarin + Phyllanthus niruri extract + choline hepatoprotective combination versus silymarin alone, even if the dose of silymarin in combination was smaller than the dose of silymarin alone. The superior efficacy of the combination in terms of individual parameters was more evident in the group with a more severe pathology, where the degree of inflammation and destruction is higher.
\end{abstract}

\section{Rezumat}

Afecțiunile hepatice cronice la adult reprezintă unul dintre cele mai importante aspecte ale practicii medicale curente din cauza prevalenței și incidenței mari. Diferitelor afecțiuni hepatice le sunt adresate un număr de medicamente de sinteză, dar și de origine vegetală, cele de origine vegetală având un profil de siguranță net superior. Cel mai studiat şi utilizat remediu vegetal pentru patologiile hepatice este extractul din semințe de Silybum marianum standardizat în silimarină. Produselor vegetale însă li se impută de cele mai multe ori o eficiență mai redusă compensată prin nevoia de a administra doze mari și multiple într-un tratament de lungă durată. De aceea, ideea combinării mai multor hepatoprotectoare care să producă un efect sinergic apare logică și necesară. Aceasta cercetare și-a popus să evalueze efectul hepatoprotector al combinaţiei silimarină, extract de Phyllanthus niruri și colină comparativ cu efectul silimarinei singure, dar în doză mai mare, în diverse afecțiuni hepatice. Pacienții incluși au fost adulți diagnosticați cu diverse patologii hepatice (hepatită virală B sau C, ciroză hepatică compensată, steatohepatita) și apoi distribuiți randomizat în două grupuri de tratament hepatoprotector. Tratamentul hepatoprotector a fost administrat zilnic timp de 180 de zile, iar pacienții au fost investigați la includere, după 3 și 6 luni de tratament pentru biomarkeri specifici și Fatty liver index (FLI) ca parametru al gradului de steatoză hepatică. Rezultatele au demonstrat eficacitatea superioară a combinației hepatoprotectoare silimarină + Phyllanthus + colină față de silimarină singură, chiar dacă doza de silimarină din combinație a fost mai mică decât cea utilizată individual. Eficacitatea superioară a combinației în ceea ce privește parametrii individuali testați a fost mai evidentă în grupul cu afecțiuni mai severe, caracterizate prin grad de inflamație şi grad de distrucție hepatocelulară mai pronunțat.

Keywords: silymarin, Phyllanthus, choline, hepatoprotective, steatosis, hepatitis, cirrhosis

\section{Introduction}

Chronic liver diseases in adults represent one of the most important part of our daily practice due to a high prevalence and incidence worldwide.
In Romania scarce data is available regarding their epidemiology, most of the studies being of not very recent topicality.

Regarding viral causes of hepatitis in Romania, chronic infection with HBV (estimated by the presence of HBs 
antigen in the serum), we can report an approximately $4.4 \%$ prevalence in the adult population [12] and $3.23 \%$ prevalence of $\mathrm{HCV}$ (estimated by the presence of HCV antibodies in the serum) [11]. In Romania, the HDV is found in about $23 \%$ of the people chronically infected with HBV [10].

Non-alcoholic fatty liver disease (NAFLD) and nonalcoholic steatohepatitis (NASH) are two of the most frequently encountered hepatic disorders, with different prevalence throughout the world, with a global prevalence of $25-30 \%$ for NAFLD and 2 $3 \%$ for NASH [4]. In Romania, the prevalence of NAFLD was estimated at about $20 \%$ in 2008 [25, 27] but presumably it is now at much higher levels. Advanced liver diseases known as liver cirrhosis, as possible and classic final path of any liver damage, have been estimated to increase and become the $12^{\text {th }}$ leading cause of death in 2020 [19]. From 2005 to 2015, the global age-standardised prevalence of liver cirrhosis due to alcohol has increased by $16.1 \%$, compared with HBV (11.9\%), HCV (14.2\%) and others $(9.9 \%)$ [26].

A number of synthetic drugs, but also plant-based drugs, are used for various liver diseases. Synthetic drugs, although highly effective, come with adverse effects that make the treatment difficult to tolerate or can severely affect other organs. From this point of view, some plant-based drugs have a clearly better safety profile [28]. The most studied and used plant-based remedy for hepatic disorders is Silybum marianum seeds extract standardized in silymarin, a flavonolignanic complex of three flavones: silybin, silydianin and silychristin. The hepatoprotective action of this pharmacological complex, is based on two mechanisms: protection of the outer structure of the hepatocyte membrane due to its highly antioxidant potential [9], strong anti-inflammatory effect [6], antifibrotic effect [16], ability to preserve reduced glutathione [21] and its immunostimulatory effect [29]; the stimulation of polymerase A with an enhanced effect on the ribosomal protein synthesis responsible for the increase of hepatic regeneration and the neogenesis of hepatocytes [14].

The complex action of silymarin has been confirmed in numerous clinical studies which clearly demonstrate that silymarin lowers the level of serum transaminases as compared to the initial status and to placebo in patients with various hepatic disorders (viral hepatitis B or C, other causes of chronic hepatitis) [17].

However, plant-based products are often described as having a lower efficacy, which entails the need of higher and multiple doses in a long-time treatment. That is why the idea of a combination between several hepatoprotectives for a synergistic effect arises as logical and necessary.

The Phyllanthus niruri extract, although used for over 2000 years in the traditional medicine in Southeast Asia and the Amazon and then confirmed by modern medicine as a diuretic and antilithiatic, has recently come to the researchers' attention for the particularly effective antioxidant and hepatoprotective effects confirmed in both animal $[2,3,5]$ and clinical studies [15]. In addition, more and more clinical studies confirm that Phyllanthus is effective in HBsAg, HBeAg and HBV DNA clearance and also in serum hepatic enzymes normalization as compared to synthetic antiviral drugs (lamivudin, alpha-interferon, thymozin and alphathymozin) but without the adverse effects specific to antiviral drugs [31].

Choline is included in the $\mathrm{B}$ vitamins and is a component of phosphatidylcholine and an active element of lecithin. The liver uses choline as a source for the methyl group in trans-methylation reactions, and as an activator of thrombocytes and plasminogen. Choline is also part of the cell membrane and of plasmatic lipoproteins. It is a fact that choline deficiency is connected with hepatic lesions (increased serum levels of alanine-aminotransferase) and with hepatic steatoses in patients parenterally fed with nutritive solutions without choline [7] and in menopausal women whose diet is deficient in choline, or is adequate in methionine, folic acid and vitamin B12, but deficient in choline [13]; these effects can be reversible after a supplementary intake of choline.

Due to the fact that in our country liver protection supplements come second in place among the main categories of dietary supplements that people buy $(13.8 \%)$, it is advisable to have on the market drugs that are backed up by rigorous studies [18] and nutrivigilance for all botanical compounds should be a mainstay in this field [23].

The present research aimed to evaluate the hepatoprotective effect of the combination silymarin + Phyllanthus niruri extract + choline (capsules) versus the effect of silymarin alone in higher concentration in patients with hepatic disorders of different causes.

\section{Materials and Methods}

\section{Study population}

The study enrolled patients from a Gastroenterology outpatient clinic from Oradea, Romania, between October 2016 and June 2018. Enrolment was conditioned by the informed free consent signed by the patient. The study was approved by the clinic Ethics Committee.

Inclusion criteria: adult patients with hepatic disorders by different causes (viral hepatitis with virus B or C, compensated cirrhosis, steatohepatitis), a degree of hepatic damage defined by serum transaminases: AST and/or ALT $=1.5-5 \times$ normal values and/or gamma glutamyl transpeptidase values $(\mathrm{GGT})=1.5-7 \times$ normal values.

Exclusion criteria: patients younger than 18, patients with known hypersensitivity to any ingredients from any studied product, pregnancy and nursing, patients 
with severe hepatic disorders like decompensated cirrhosis (Child Pugh B and C), hepatic neoplasm, acute viral hepatitis, patients that at the enrolment time were undergoing antiviral therapy (interferon, nucleoside/nucleotide analogues, ribavirin, interferonfree medication).

Study design

The study design was open, but randomised. The included patients were distributed in one of the study groups by a randomisation program with closed envelopes. The first group received as hepatoprotective treatment silymarin $150 \mathrm{mg}$ (Hepatoprotect forte ${ }^{\circledR}$, Biofarm, Romania) three times per day, 180 days and the second group the combination silymarin $120 \mathrm{mg}+$ Phyllanthus niruri extract standardized in phyllantines $1.5 \%, 225 \mathrm{mg}+$ choline $60 \mathrm{mg}$ (Stoptoxin forte ${ }^{\circledR}$, Fiterman Pharma, Romania) three times per day, 180 days.

Evaluation criteria and outcomes

At the initial visit (baseline) the patients were evaluated for clinical and paraclinical features. The patients underwent an abdominal ultrasound and parameters of hepatocytolisis (AST, ALT), cholestasis (GGT, bilirubin) and total cholesterol were recorded.

All these biochemical analyses were performed using an Advia 1800 analyser manufactured by Siemens. For ALT, AST, GGT we used the modified International Federation of Clinical Chemistry (IFCC) method with the following reagents: Siemens Healthcare Diagnostics, ref. 07499718 (for AST), Siemens Healthcare Diagnostics, ref.07501976 (for ALT) and Siemens Healthcare Diagnostics, ref. 02011954 (for GGT). Regarding bilirubin, we used the vanadate oxidation method and Siemens Healthcare Diagnostics, ref. 02188064 as reagent. For lipid measurements, we used GPO-

Trinder without serum blank method and Siemens Healthcare Diagnostics, ref. 10335892 as reagent. Fatty liver index (FLI) as a parameter for the degree of hepatic steatosis was also calculated.

The patients were asked to come back for a second visit after 90 days of treatment and for the third visit after 180 days of treatment. At each visit the results of the biochemical tests described above were recorded, as well as the adverse effects occurred during the treatment. The patients were not asked to discontinue any other concomitant medication for their associated pathology. Statistical analysis

All the parameters tested in each group and each visit, were calculated for average and standard deviation, percentage change from the initial average value, and the percentage of values falling into the normal range. According with FLI definition, a FLI < 30 was considered as normal (negative for steatosis diagnostic) [1]. For each visit in each group the statistical significance of the change from baseline for each parameter was tested using the F-test, with significance for $\mathrm{p}<0.05$. For the last visit, relative risk and NNT (number needed to treat) for non-achieving normal values for all three hepatic enzymes at the same significance level was calculated, an analysis with more clinical relevance.

\section{Results and Discussion}

After applying the inclusion and exclusion criteria to the studied population there was an initial group of 100 patients with hepatic disorders. During the study, 14 patients withdrew for personal reasons or died due to aggravation of liver pathology, ultimately resulting in a group of 86 patients with features described in Table I.

Table I

Baseline characterisation of the patients

\begin{tabular}{|c|c|c|c|}
\hline Treatment & Silymarin & Silymarin + Phyllanthus niruri + choline & $\mathrm{p}$ value \\
\hline Number of patients & $\mathrm{N}=45$ & $\mathrm{~N}=41$ & \\
\hline $\begin{array}{r}51 \text { men }(59.3 \%) \\
35 \text { women }(40.69 \%)\end{array}$ & $\begin{array}{l}M=25 \\
F=20\end{array}$ & $\begin{array}{l}M=26 \\
F=15\end{array}$ & $\mathrm{p}=0.46$ \\
\hline Age (mean) & 56.08 (range $25-78$ years) & 53.90 (range $31-80$ years) & $\mathrm{p}=0.35$ \\
\hline AST, U/L (mean) & 75.22 & 86.26 & $p=0.36$ \\
\hline ALT, U/L (mean) & 67.35 & 81.59 & $p=0.23$ \\
\hline GGT, U/L (mean) & 150.75 & 213.51 & $\mathrm{p}=0.07$ \\
\hline Bilirubin, $\mathrm{mg} / \mathrm{dL}$ (mean) & 1.10 & 1.27 & $p=0.38$ \\
\hline Cholesterol, mg/dL (mean) & 181.75 & 184.85 & $\mathrm{p}=0.79$ \\
\hline Triglycerides, $\mathrm{mg} / \mathrm{dL}$ (mean) & 125 & 123.19 & $\mathrm{p}=0.88$ \\
\hline FLI & 72.12 & 77.10 & $\mathrm{p}=0.35$ \\
\hline \multicolumn{4}{|l|}{ Pathologies } \\
\hline Steatohepatitis & 12 patients & 17 patients & \\
\hline Toxic nutritional cirrhosis & 15 patients & 11 patients & \\
\hline Viral hepatitis C & 9 patients & 6 patients & \\
\hline Viral C cirrhosis & 5 patients & 4 patients & \\
\hline Drug-induced hepatitis & 1 patient & 1 patient & \\
\hline Viral hepatitis B & 2 patients & 2 patients & \\
\hline Other causes of chronic hepatitis & 1 patient & - & \\
\hline
\end{tabular}


FARMACIA, 2020, Vol. 68, 2

The initial global analysis of the two treatment groups shows a decrease in the values of the studied parameters, but also a higher degree of individual parameters normalization in the group that received the combination Silymarin + Phyllanthus niruri + choline (Table II).

Table II

Global analysis of the studied parameters during the hepatoprotective treatment

\begin{tabular}{|c|c|c|c|c|c|c|c|}
\hline & \multicolumn{3}{|c|}{ Silymarin } & \multicolumn{3}{|c|}{ Silymarin + Phyllanthus niruri + choline } & \\
\hline \multicolumn{8}{|c|}{ AST (U/l) } \\
\hline & $\begin{array}{c}\text { Average } \\
( \pm \text { SD })\end{array}$ & $\begin{array}{l}\% \text { change } \\
v s \text { initial }\end{array}$ & $\begin{array}{c}\% \text { normal } \\
\text { values }\end{array}$ & Average $( \pm \mathrm{SD})$ & $\begin{array}{l}\% \text { change } \\
\text { vs initial }\end{array}$ & $\begin{array}{c}\% \text { normal } \\
\text { values }\end{array}$ & $\mathrm{p}$ value \\
\hline Baseline & $75.22 \pm 58.13$ & & $22.22 \%$ & $86.26 \pm 53.82$ & & $12.19 \%$ & \\
\hline Visit 1 & $48.08 \pm 46.81$ & $-36.07 \%$ & $46.66 \%$ & $44.63 \pm 30.77$ & $-48.25 \%$ & $46.34 \%$ & \\
\hline Visit 2 & $48.08 \pm 50.69^{*}$ & $-36.07 \%$ & $57.77 \%$ & $34.28 \pm 18.84 *$ & $-60.27 \%$ & $63.41 \%$ & $* \mathrm{p}<0.05$ \\
\hline \multicolumn{8}{|c|}{$\operatorname{ALT}(\mathbf{U} / \mathbf{L})$} \\
\hline Baseline & $67.35 \pm 53.83$ & & $37.77 \%$ & $81.59 \pm 56.63$ & & $29.26 \%$ & \\
\hline Visit 1 & $42.8 \pm 34.21$ & $-36.45 \%$ & $55.55 \%$ & $44.04 \pm 28.60$ & $-46.01 \%$ & $60.97 \%$ & \\
\hline Visit 2 & $43.2 \pm 32.69 *$ & $-35.86 \%$ & $57.77 \%$ & $34.87 \pm 19.77 *$ & $-57.25 \%$ & $75.60 \%$ & $* \mathrm{p}<0.05$ \\
\hline \multicolumn{8}{|c|}{ GGT (U/L) } \\
\hline Baseline & $150.75 \pm 113.78$ & & $17.77 \%$ & $213.51 \pm 200.69$ & & $17.07 \%$ & \\
\hline Visit 1 & $103.86 \pm 106.711$ & $-31.10 \%$ & $44.44 \%$ & $136.36 \pm 131.25$ & $-36.13 \%$ & $36.58 \%$ & \\
\hline Visit 2 & $121.2 \pm 138.57^{*}$ & $-19.60 \%$ & $51.11 \%$ & $95.24 \pm 87.16^{*}$ & $-55.39 \%$ & $51.21 \%$ & $* \mathrm{p}<0.05$ \\
\hline \multicolumn{8}{|c|}{ Bilirubin $(\mathrm{mg} / \mathrm{dL})$} \\
\hline Baseline & $1.104 \pm 0.56$ & & $64.44 \%$ & $1.278 \pm 1.20$ & & $68.29 \%$ & \\
\hline Visit 1 & $1.13 \pm 0.74$ & $+2.99 \%$ & $66.66 \%$ & $0.95 \pm 0.52$ & $-24.90 \%$ & $75.60 \%$ & \\
\hline Visit 2 & $0.96 \pm 0.66^{*}$ & $-12.96 \%$ & $77.77 \%$ & $0.94 \pm 0.59 *$ & $-26.18 \%$ & $82.92 \%$ & $* \mathrm{p}=0.21$ \\
\hline \multicolumn{8}{|c|}{ Cholesterol (mg/dL) } \\
\hline Baseline & $181.75 \pm 45.14$ & & $71.11 \%$ & $189.73 \pm 56.66$ & & $53.65 \%$ & \\
\hline Visit 1 & $173.97 \pm 43.26$ & $-4.2 \%$ & $73.33 \%$ & $177.19 \pm 51.74$ & $-6.6 \%$ & $73.17 \%$ & \\
\hline Visit 2 & $187.62 \pm 50.17$ * & $+3.22 \%$ & $68.88 \%$ & $174.70 \pm 48.44 *$ & $-7.9 \%$ & $73.17 \%$ & $* p=0.41$ \\
\hline \multicolumn{8}{|c|}{ Triglycerides (mg/dL) } \\
\hline Baseline & $125 \pm 56.35$ & & $68.88 \%$ & $123.19 \pm 60.75$ & & $78.04 \%$ & \\
\hline Visit 1 & $118.46 \pm 70.81$ & $-5.22 \%$ & $80 \%$ & $129.58 \pm 88.69$ & $+5.18 \%$ & $70.72 \%$ & \\
\hline Visit 2 & $166.6 \pm 244.48^{*}$ & +33.28 & $71.11 \%$ & $155.02 \pm 206.06^{*}$ & $+25.83 \%$ & $80.48 \%$ & $* p=0.13$ \\
\hline \multicolumn{8}{|c|}{ FLI } \\
\hline Baseline & $72.12 \pm 27.67$ & & $8.88 \%$ & $77.10 \pm 21.12$ & & $21.95 \%$ & \\
\hline Visit 1 & $60.56 \pm 31.19$ & $-16.02 \%$ & $51.11 \%$ & $72.43 \pm 24.93$ & $-6.05 \%$ & $21.95 \%$ & \\
\hline Visit 2 & $61.88 \pm 30.72 *$ & $-14.18 \%$ & $42.22 \%$ & $66.30 \pm 27.78 *$ & $-14.00 \%$ & $36.58 \%$ & $* p=0.26$ \\
\hline
\end{tabular}

The biological evolution of patients regarding normalization of the enzymes AST, ALT and GGT is presented in Figure 1. For visit 2, at 6 months from baseline we also calculated RR 0.92, CI $95 \%$ $[0.67,1.2], \mathrm{p}=0.29$.

However, considering that the pathologies of the patients included in the study are characterized by different degrees of steatosis, inflammation and, consequently of hepatocytolisis, a breakdown analysis on two pathology groups was performed: patients within the steatohepatitis group, with a lower degree of inflammation and less intense hepatocytolisis; patients with hepatitis or liver cirrhosis, with a higher degree of inflammation and with intense hepatocytolisis.

Following this analysis, in each treatment group resulted 2 subgroups of patients that were analysed separately (Tables III and IV).

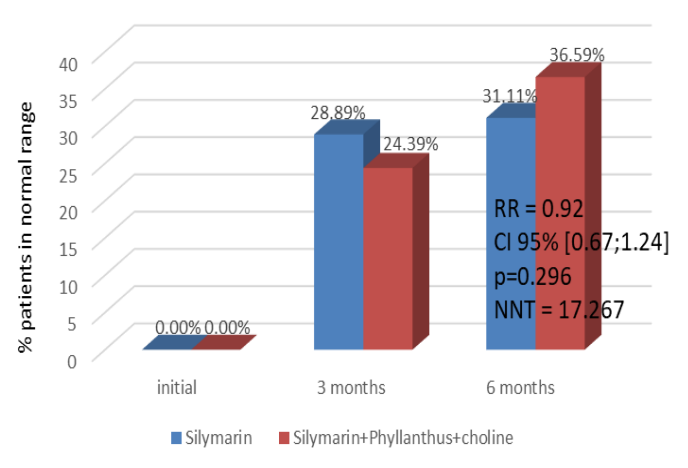

Figure 1.

Global analysis for patients with normalization of AST, ALT and GGT 
Table III

Analysis of the evolution of studied parameters in patients with hepatitis and/or cirrhosis of different causes

\begin{tabular}{|c|c|c|c|c|c|c|c|}
\hline & \multicolumn{3}{|c|}{ Silymarin } & \multicolumn{3}{|c|}{ Silymarin + Phyllanthus niruri + choline } & \\
\hline \multicolumn{8}{|c|}{ AST (U/L) } \\
\hline & Average $( \pm \mathrm{SD})$ & $\begin{array}{l}\% \text { change } \\
v s \text { initial }\end{array}$ & $\begin{array}{c}\% \text { normal } \\
\text { values }\end{array}$ & Average $( \pm \mathrm{SD})$ & $\begin{array}{c}\% \text { change } \\
v s \text { initial }\end{array}$ & $\begin{array}{c}\% \text { normal } \\
\text { values }\end{array}$ & $\mathrm{p}$ value \\
\hline Baseline & $79.05 \pm 58.30$ & & $14.28 \%$ & $98.70 \pm 57.60$ & & $3.70 \%$ & \\
\hline Visit 1 & $54.05 \pm 51.28$ & $-31.62 \%$ & $42.85 \%$ & $50.18 \pm 34.39$ & -49.15 & $40.74 \%$ & \\
\hline Visit 2 & $52.71 \pm 56.44^{*}$ & $-33.32 \%$ & $57.14 \%$ & $36.40 \pm 21.13^{*}$ & -63.11 & $70.37 \%$ & $* \mathrm{p}<0.05$ \\
\hline \multicolumn{8}{|c|}{ ALT (U/L) } \\
\hline Baseline & $63.0 \pm 38.11$ & & $51.42 \%$ & $86.44 \pm 57.87$ & & $40.74 \%$ & \\
\hline Visit 1 & $42.4 \pm 34.52$ & $-32.69 \%$ & $77.14 \%$ & $46.88 \pm 30.70$ & $-45.75 \%$ & $70.37 \%$ & \\
\hline Visit 2 & $42.14 \pm 33.77 *$ & $-33.10 \%$ & $82.85 \%$ & $36.14 \pm 22.36 *$ & $-58.18 \%$ & $85.18 \%$ & $* \mathrm{p}<0.05$ \\
\hline \multicolumn{8}{|c|}{ GGT (U/L) } \\
\hline Baseline & $146.88 \pm 92.65$ & & $17.14 \%$ & $207.74 \pm 165.46$ & & $11.11 \%$ & \\
\hline Visit 1 & $102.05 \pm 90.56$ & $-30.51 \%$ & $42.85 \%$ & $135.55 \pm 135.16$ & $-34.74 \%$ & $40.74 \%$ & \\
\hline Visit 2 & $122.45 \pm 140.09^{*}$ & $-16.63 \%$ & $51.42 \%$ & $98.07 \pm 93.75^{*}$ & $-52.79 \%$ & $48.14 \%$ & $* \mathrm{p}<0.05$ \\
\hline \multicolumn{8}{|c|}{ Bilirubin (mg/dL) } \\
\hline Baseline & $1.21 \pm 0.57$ & & $57.14 \%$ & $1.45 \pm 1.39$ & & $59.25 \%$ & \\
\hline Visit 1 & $1.23 \pm 0.79$ & $+1.07 \%$ & $62.85 \%$ & $1.04 \pm 0.61$ & -27.78 & $66.66 \%$ & \\
\hline Visit 2 & $1.029 \pm 0.72 *$ & $-15.55 \%$ & $74.28 \%$ & $0.93 \pm 0.59 *$ & -35.33 & $81.48 \%$ & $* p=0.15$ \\
\hline \multicolumn{8}{|c|}{ Cholesterol (mg/dL) } \\
\hline Baseline & $180 \pm 47.73$ & & $74.28 \%$ & $176.14 \pm 52.81$ & & $62.96 \%$ & \\
\hline Visit 1 & $175.14 \pm 46.42$ & $-2.69 \%$ & $71.42 \%$ & $172.55 \pm 37.52$ & $-2.03 \%$ & $77.77 \%$ & \\
\hline Visit 2 & $187.14 \pm 54.10 *$ & $+3.96 \%$ & $68.57 \%$ & $166.48 \pm 38.45^{*}$ & $-5.48 \%$ & $77.77 \%$ & $* \mathrm{p}<0.05$ \\
\hline \multicolumn{8}{|c|}{ Triglycerides (mg/dL) } \\
\hline Baseline & $122.54 \pm 54.52$ & & $71.42 \%$ & $112.37 \pm 57.82$ & & $85.15 \%$ & \\
\hline Visit 1 & $119.37 \pm 74.05$ & $-2.58 \%$ & $80 \%$ & $117.88 \pm 98.87$ & $+4.91 \%$ & $81.48 \%$ & \\
\hline Visit 2 & $134.22 \pm 80.90 *$ & $+9.53 \%$ & $74.28 \%$ & $129.37 \pm 211.09 *$ & $+15.12 \%$ & $96.29 \%$ & $* \mathrm{p}<0.05$ \\
\hline \multicolumn{8}{|c|}{ FLI } \\
\hline Baseline & $71.58 \pm 26.21$ & & $8.57 \%$ & $73.57 \pm 23.85$ & & $3.70 \%$ & \\
\hline Visit 1 & $60.30 \pm 31.11$ & $-15.74 \%$ & $20.0 \%$ & $67.13 \pm 27.99$ & $-8.74 \%$ & $14.81 \%$ & \\
\hline Visit 2 & $61.58 \pm 29.95 *$ & $-13.96 \%$ & $17.14 \%$ & $60.48 \pm 28.01^{*}$ & $-17.79 \%$ & $22.22 \%$ & $* \mathrm{p}=0.36$ \\
\hline
\end{tabular}

The biological evolution of patients regarding normalization of the enzymes AST, ALT and GGT in the hepatitis or cirrhosis group is presented in
Figure 2. For visit 2, at 6 months from baseline we also calculated RR 0.918, CI 95\% [0.637; 1.324], $\mathrm{p}=0.32$.

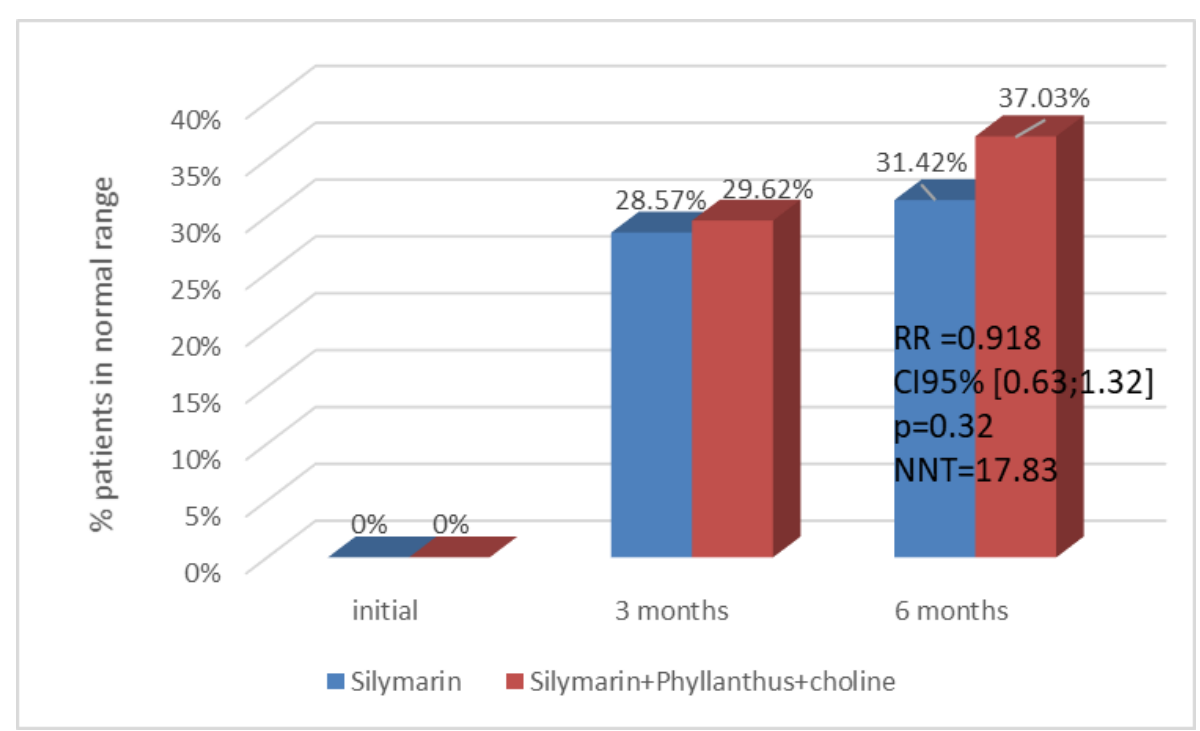

Figure 2.

Analysis of patients with normalization of AST, ALT and GGT in hepatitis \pm cirrhosis group 
Table IV

Analysis of the studied parameters evolution in patients with hepatic steatosis

\begin{tabular}{|c|c|c|c|c|c|c|c|}
\hline & \multicolumn{3}{|c|}{ Silymarin } & \multicolumn{3}{|c|}{ Silymarin + Phyllanthus niruri + choline } & \\
\hline \multicolumn{8}{|c|}{ AST $(\mathbf{U} / \mathbf{L})$} \\
\hline & Average $( \pm \mathrm{SD})$ & $\begin{array}{l}\% \text { change } \\
v s \text { initial }\end{array}$ & $\begin{array}{c}\% \text { normal } \\
\text { values }\end{array}$ & Average $( \pm \mathrm{SD})$ & $\begin{array}{l}\% \text { change } \\
v s \text { initial }\end{array}$ & $\begin{array}{c}\% \text { normal } \\
\text { values }\end{array}$ & $\mathrm{p}$ value \\
\hline Baseline & $61.8 \pm 58.51$ & & $50 \%$ & $62.26 \pm 36.52$ & & $28.57 \%$ & \\
\hline Visit 1 & $27.2 \pm 12.55$ & $-55.98 \%$ & $70 \%$ & $33.92 \pm 19.02$ & -45.50 & $64.28 \%$ & \\
\hline Visit 2 & $31.9 \pm 12.26^{*}$ & -48.38 & $70 \%$ & $30.14 \pm 13.09^{*}$ & -51.58 & $71.42 \%$ & $* \mathrm{p}=0.42$ \\
\hline \multicolumn{8}{|c|}{$\operatorname{ALT}(\mathbf{U} / \mathbf{L})$} \\
\hline Baseline & $82.6 \pm 91.36$ & & $50 \%$ & $72.23 \pm 55.03$ & & $35.71 \%$ & \\
\hline Visit 1 & $44.2 \pm 34.87$ & $-46.48 \%$ & $60 \%$ & $38.57 \pm 24.13$ & $-46.60 \%$ & $64.28 \%$ & \\
\hline Visit 2 & $46.9 \pm 29.94 *$ & $-43.22 \%$ & $50 \%$ & $32.42 \pm 13.87 *$ & $-55.10 \%$ & $85.71 \%$ & $* \mathrm{p}<0.05$ \\
\hline \multicolumn{8}{|c|}{ GGT (U/L) } \\
\hline Baseline & $164.3 \pm 174.92$ & & $20 \%$ & $224.64 \pm 262.62$ & & $28.57 \%$ & \\
\hline Visit 1 & $110 \pm 155.81$ & -33.04 & $50 \%$ & $137.92 \pm 128.30$ & $-38.60 \%$ & $28.57 \%$ & \\
\hline Visit 2 & $116.8 \pm 140.39^{*}$ & $-28.91 \%$ & $50 \%$ & $89.78 \pm 75.82 *$ & $-60.03 \%$ & $57.14 \%$ & $* \mathrm{p}<0.05$ \\
\hline \multicolumn{8}{|c|}{ Bilirubin (mg/dL) } \\
\hline Baseline & $0.701 \pm 0.31$ & & $90 \%$ & $0.945 \pm 0.61$ & & $85.71 \%$ & \\
\hline Visit 1 & $0.804 \pm 0.39$ & $+14.69 \%$ & $80 \%$ & $0.796 \pm 0.23$ & $-15.72 \%$ & $92.85 \%$ & \\
\hline Visit 2 & $0.721 \pm 0.33^{*}$ & $+2.85 \%$ & $90 \%$ & $0.953 \pm 0.59 *$ & $+0.90 \%$ & $85.71 \%$ & $* \mathrm{p}<0.05$ \\
\hline \multicolumn{8}{|c|}{ Cholesterol (mg/dL) } \\
\hline Baseline & $187.9 \pm 36.12$ & & $60 \%$ & $215.92 \pm 56.38$ & & $35.71 \%$ & \\
\hline Visit 1 & $169.9 \pm 31.39$ & $-9.57 \%$ & $80 \%$ & $186.13 \pm 72.74$ & $-13.79 \%$ & $64.28 \%$ & \\
\hline Visit 2 & $189.3 \pm 35.28^{*}$ & $+0.74 \%$ & $70 \%$ & $190.57 \pm 62.06^{*}$ & $-11.74 \%$ & $64.28 \%$ & $* \mathrm{p}<0.05$ \\
\hline \multicolumn{8}{|c|}{ Triglycerides (mg/dL) } \\
\hline Baseline & $133.6 \pm 64.69$ & & $60 \%$ & $144.07 \pm 62.89$ & & $64.28 \%$ & \\
\hline Visit 1 & $115.3 \pm 61.49$ & $-13.69 \%$ & $80 \%$ & $152.14 \pm 61.82$ & $+5.6 \%$ & $50 \%$ & \\
\hline Visit 2 & $279.9 \pm 499.16^{*}$ & $+109.50 \%$ & $60 \%$ & $204.5 \pm 193.72 *$ & $+41.94 \%$ & $50 \%$ & $* p<0.05$ \\
\hline \multicolumn{8}{|c|}{ FLI } \\
\hline Baseline & $74.002 \pm 33.82$ & & $10 \%$ & $83.9 \pm 12.60$ & & 0 & \\
\hline Visit 1 & $61.46 \pm 33.15$ & $-16.94 \%$ & $10 \%$ & $82.65 \pm 13.23$ & $-1.48 \%$ & 0 & \\
\hline Visit 2 & $62.94 \pm 35.00^{*}$ & $-14.93 \%$ & $20 \%$ & $77.53 \pm 24.48 *$ & $-7.58 \%$ & $7.14 \%$ & $* p=0.11$ \\
\hline
\end{tabular}

The biological evolution of patients regarding normalization of the enzymes AST, ALT and GGT in the steatosis group is presented in Figure 3. For visit 2, at 6 months from baseline we also calculated RR 0.803, CI 95\% [0.48; 1.323], $\mathrm{p}=0.19$.

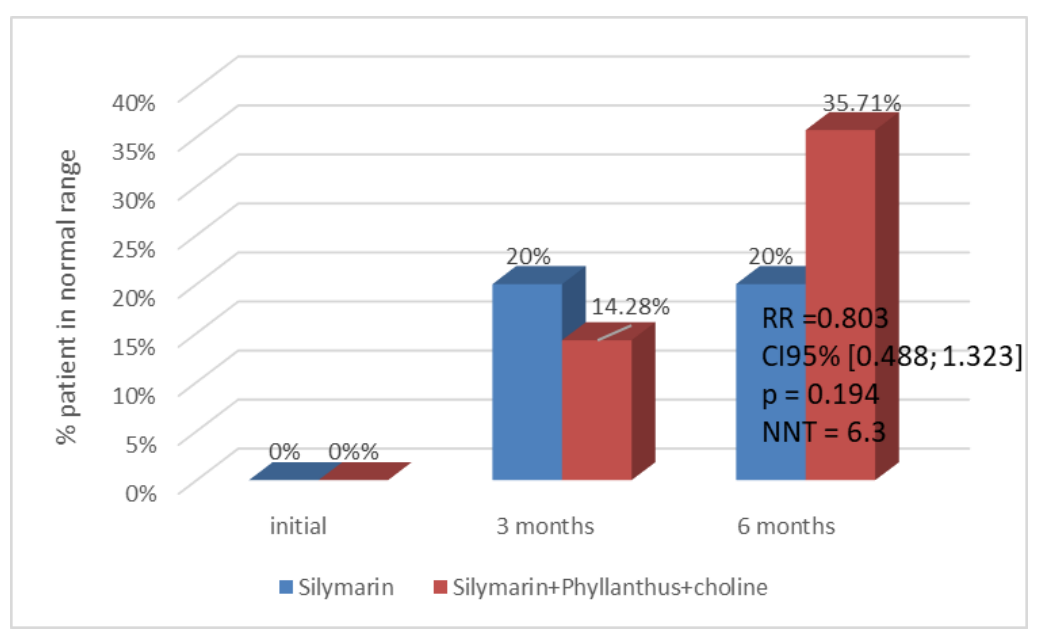

Figure 3.

Analysis of patients with normalization of AST, ALT and GGT in the steatosis group

No patient reported any adverse effect correlated to the hepatoprotective treatment.

Our initial global analysis showed that in the group that received the combination silymarin + Phyllanthus niruri + choline, the values for hepatocytolisis markers (AST and ALT) and GGT individually at the end of the treatment period (180 days) were significantly improved than the values recorded for the group that 
received silymarin alone, considering both nominal values and percentage of normal values. The analysis for all three enzymes demonstrated also a higher percent of patients with normalised values in silymarin + Phyllanthus niruri + choline group, but with not enough significance (Figure 1).

These results confirm the more efficient antioxidant and hepatoprotective action of silymarin + Phyllanthus niruri + choline combination versus silymarin alone. Moreover, the silymarin + Phyllanthus combination had been previously reported to have a synergistic hepatoprotective effect unlike the effect of the individual component in animal studies [30] and in clinical studies on patients with non-alcoholic fatty liver disease (NAFLD) [4]. This effect is based on the well-known antioxidant properties of silymarin, but also on those of the more recently studied Phyllanthus niruri extract. Thus, for the extract of Phyllanthus niruri (amarus), a decrease in lipid peroxidase (LPO) activity and an increase in superoxide dismutase (SOD), glutathione peroxides (GPx), catalase, and vitamins $\mathrm{E}$ and $\mathrm{C}$ activity were confirmed clinically in patients with viral hepatitis B [22]. The other parameters values were not significantly different.

But the breakdown analysis on different pathologies reveals a different picture: in the hepatitis/cirrhosis group hepatocytolisis markers (AST, ALT) and GGT confirm the trend recorded from our global analysis with significantly better results for the group that received the combination silymarin + Phyllanthus niruri + choline. But in this pathology group cholesterol and triglycerides were also significantly lower in patients from the silymarin + Phyllanthus niruri + choline group as compared to the silymarin group with a higher percent of results into the normal range. Bilirubin and FLI values were not significantly different in the two groups.

These results confirm a superior hepatoprotective and antioxidant action of the combination silymarin + Phyllanthus niruri + choline versus silymarin alone. The present research results are in line with other researches for silymarin as hepatoprotective intervention in different hepatic disorders that demonstrated that similar doses of silymarin as in our study decrease the hepatocytolisis markers [24].

In hepatic steatosis, only AST values were not significantly different in the two groups; however, at the end of the treatment the percentage of values falling into normal range was higher in the combination group than in the silymarin group. These results and the decreasing trend for the other two enzymes confirm the superior efficacy of the studied combination in this pathology group also, as previously reported by other studies [20]. Bilirubin, cholesterol and triglycerides also revealed significantly different results between the two hepatoprotective treatments, but the percentage of normal results were similar.
The results of the breakdown analysis on hepatic pathologies with different severity and different degrees of hepatic destruction demonstrate that in more severe pathologies with more pronounced inflammation and more advanced hepatocytolisis the efficacy of the hepatoprotective combination silymarin + Phyllanthus niruri + choline is more evident. In pathologies with less inflammation the superior efficacy of this combination is still evident, but the trend is flattened, probably because of less severe disorders. However, the results of normalised values for all three enzymes are still superior with silymarin + Phyllanthus niruri + choline combination in both pathology groups, but are more significant in the steatosis group (Figures 2 and 3). These data should be further investigated on a larger number of patients for more accurate results, since the pathology groups included a rather small number of patients.

Both hepatoprotective treatments were well tolerated, since no group reported any adverse effects correlated to the hepatoprotective treatment.

\section{Conclusions}

The hepatoprotective combination silymarin + Phyllanthus niruri + choline proved to be more efficient than silymarin alone in hepatic disorders of different aetiologies (including non-alcoholic steatohepatitis) and with different inflammation and destruction stages, even if the silymarin dose used in combination with Phyllanthus niruri and choline is smaller than the dose used for silymarin alone.

As of our knowledge the present study also demonstrates for the first time the efficacy of the combination silymarin + Phyllanthus niruri + choline in other hepatic disorders with more important inflammatory and destructive picture.

\section{Conflict of interest}

The authors declare no conflict of interest.

\section{References}

1. Bedogni G, Bellentani S, Miglioli L, Masutti F, Passalacqua M, Castiglione A, Tiribelli C, The Fatty Liver Index: a simple and accurate predictor of hepatic steatosis in the general population. $B M C$ Gastroenterol., 2006; 6: 1-7.

2. Bhattacharjee R, Sil PC, Protein isolate from the herb, Phyllanthus niruri L. (Euphorbiaceae), plays hepatoprotective role against carbontetrachloride induced liver damage via its antioxidant properties. Food Chem Toxicol., 2007; 45(5): 817-826.

3. Bhattacharjee R, Sil PC, The protein fraction of Phyllanthus niruri plays a protective role against acetaminophen induced hepatic disorder via its antioxidant properties. Phytother Res., 2006; 20(7): 595-601.

4. Călin-Necula A, Moldoveanu A, Peagu R, Viațu O, Săraru R, Petrişor A, Oprea G, Sârbu E, Tribus L, 
Usvat R, Fierbințeanu-Braticevici C, Antioxidant therapy in non-alcoholic steatohepatitis. Medicina Internă, 2017; 14(3): 16-23, (available in Romanian).

5. Chatterjee M, Sil PC, Hepatoprotective effect of aqueous extract of Phyllanthus niruri on nimesulideinduced oxidative. Indian J Biochem Biophys., 2006; 43(5): 299-305.

6. Dehmlow C, Erhard J, de Groot H, Inhibition of Kupffer cell functions as an explanation for the hepatoprotective properties of silibinin. Hepatology, 1996; 23(4): 749-754.

7. Dubin MD, Moukarzel AA, Jenden DJ, Roch M, Rice KM, Gornbein J, Ament ME, Choline deficiency: a cause of hepatic steatosis during parenteral nutrition that can be reversed with intravenous choline supplementation. Hepatology, 1995; 22(5): 1399-403.

8. European Association for the Study of the Liver (EASL), European Association for the Study of Diabetes (EASD), European Association for the Study of Obesity (EASO), EASL-EASD-EASO Clinical Practice Guidelines for the management of nonalcoholic fatty liver disease. J Hepatol., 2016; 64(6): 1388-402.

9. Feher J, Lang I, Nekam K, Muzes G, Deak G, Effect of free radical scavengers on superoxide dismutase (SOD) enzyme in patients with alcoholic cirrhosis. Acta Medica Hungarica, 1988; 45(3-4): 265-276.

10. Gheorghe L, Csiki IE, Iacob S, Hepatitis Delta Virus Infection in Romania: Prevalence and Risk Factors. J Gastrointestin Liver Dis., 2015; 24(4): 413-421.

11. Gheorghe L, Csiki IE, Iacob S, Gheorghe C, Smira G, Regep L, The prevalence and risk factors of hepatitis $\mathrm{C}$ virus infection in adult population in Romania: a nationwide survey 2006 - 2008. J Gastrointest Liver Dis., 2010; 19(4): 373-379.

12. Gheorghe L, Csiki IE, Iacob S, Gheorghe C, The prevalence and risk factors of hepatitis B virus infection in an adult population in Romania: a nationwide survey. Eur J Gastroenterol Hepatol., 2013; 25(1): 56-64.

13. Guerrerio AL, Colvin RM, Schwartz AK, Molleston JP, Choline intake in a large cohort of patients with nonalcoholic fatty liver disease. Am J Clin Nutr., 2012; 95(4): 892-900.

14. Leng-Peschlow E, Properties and medical use of flavonolignans (Silymarin) from Silybum marianum. Phytother Res., 1996; 10(1): 25-26.

15. Liu J, Lin H, McIntosh H, Genus Phyllanthus for chronic hepatitis B virus infection: a systematic review. J Viral Hepat., 2001; 8(5): 358-366.

16. Masini A, Ceccarelli D, Giovannini F, Montosi G, Garuti C, Pietrangelo A, Iron-induced oxidant stress leads to irreversible mitochondrial dysfunctions and fibrosis in the liver of chronic iron-dosed gerbils. The effect of silybin. J Bioenerg Biomembr., 2000; 32(2): 175-182.

17. Mayer KE, Myers R, Silymarin treatment of viral hepatitis: a systematic review. J Viral Hepatitis, 2005; 12: 559-567.
18. Morgovan C, Ghibu S, Juncan AM, Rus LL, Butucă A, Vonica L, Muntean A, Moş L, Gligor F, Olah NK, Nutrivigilance: A new activity in the field of dietary supplements. Farmacia, 2019; 67(3): 537-544.

19. Murray CJ, Lopez AD, Alternative projections of mortality and disability by cause 1990-2020: Global Burden of Disease Study. Lancet, 1997; 349: 14981504.

20. Năftănăilă-Mali F, Negoiță IA, Năftănăilă-Mali DE, Robu G, The evaluation of hepatoprotective effect of silymarin, Phyllanthus niruri extract and choline combination. Rev Med Chir Soc Med Nat., 2018; 122(2): 267-275.

21. Neuman MG, Cameron RG, Haber JA, Katz GG, Malkiewicz IM, Shear NH, Inducers of cytochrome P450 2E1 enhance methotrexate-induced hepatocytoxicity. Clin Biochem., 1999; 32(7): 519-536.

22. Nikam PS, Nikam SV, Sontakke AV, Lipid peroxidation and antioxidants during treatment of hepatitis-B, with Phyllanthus amarus. Int J Biol Med Res., 2010; 1(3): 41-43.

23. Păduraru DN, Coman F, Ozon EA, Gherghiceanu F, Andronic O, Ion D, Stănescu M, Bolocan A, The use of nutritional supplement in Romanian patients attitudes and beliefs. Farmacia, 2019; 67(6): 10601065.

24. Polyak SJ, Ferenci P, Pawlotsky JM, Hepatoprotective and antiviral functions of silymarin components in HCV infection. Hepatology, 2013; 57(3): 1262-1271.

25. Radu C, Grigorescu M, Crisan D, Lupsor M, Constantin D, Dina L, Prevalence and associated risk factors of non-alcoholic fatty liver disease in hospitalized patients. J Gastrointestin Liver Dis., 2008; 17(3): 255-260.

26. Rehm J, Taylor B, Mohapatra S, Irving H, Baliunas D, Patra J, Roerecke M, Alcohol as a risk factor for liver cirrhosis: a systematic review and meta-analysis. Drug Alcohol Rev., 2010; 29(4): 437-445.

27. Sanyal A, Martin A, Cadarette S, A systematic literature review of the epidemiology and economic burden associated with non-alcoholic steatohepatitis. $J$ Hepatol., 2016; 64: S475.

28. Shirani M, Raeisi R, Heidari-Soureshjani S, AsadiSamani M, Luther T, A review for discovering hepatoprotective herbal drugs with least side effects on kidney. J Nephropharmacol., 2017; 6(2): 38-48.

29. Wilasrusmee C, Kittur S, Shah G, Immunostimulatory effect of Silybum marianum (milk thistle) extract. Med SciMonit., 2002; 8(11): 439-443.

30. Yandav N, Pal, A, Shanker K, Bawankule D, Gupta A, Darokar M, Khanuja S, Synergistic effect of silymarin and standardized extract of Phyllanthus amarus against $\mathrm{CCl} 4$-induced herpatotoxicity in Rattus norvegicus. Phytomedicine, 2008; 15: 1053-1061.

31. Yun X, Hui L, Jian Ping L, Christian G, Phyllanthus species versus antiviral drugs for chronic hepatitis $\mathrm{B}$ virus infection. Cochrane Hepato-Biliary Group, 2013; 4: 1-17. 